\title{
SISTEM INFORMASI PEMASARAN PRODUKSI \\ BUAH PALA DAN HASIL OLAHANNYA PADA \\ HOME INDUSTRY VISTA DI KABUPATEN \\ FAKFAK
}

Deisya Maulida Al Hamid ; M. Guntur Namudat

Politeknik Negeri Fakfak

\begin{abstract}
Abstrak
Pemasaran merupakan hal yang sangat krusial bagi sebuah usaha. Produk yang berkualitas didukung teknik produksi yang canggih, skill pekerja yang mumpuni, ataupun modal yang mencukupi tidak akan berarti banyak bagi sebuah bidang usaha tanpa didukung kemampuan memasarkan produk yang memadai. Pemasaran yang selama ini dilakukan kelompok Vista masih sangat sederhana dengan metode promosi dari mulut ke mulut sehingga dibutuhkan sebuah metode pemasaran modern yang dapat membantu kelompok tersebut dalam memasarkan hasil produksi buah pala dan hasil olahannya, agar mampu bersaing dengan produk-produk lainnya di pasaran.

Penelitian ini ditujukan untuk mengenalkan konsep pemasaran global dengan ruang lingkup yang lebih luas yang dapat diterapkan Home Industry Vista untuk meningkatkan pendapatannya dengan konsep E-Commerce. Serta merancang sebuah website sebagai sistem informasi pemasaran produksi buah Pala dan hasil olahannya pada usaha kecil Vista di kampung Sekban kabupaten Fakfak.

Pada akhirnya penelitian ini berhasil mengenalkan konsep pemasaran dengan berbasis aplikasi (e-commerce) kepada home industry Vista dan diharapkan dapat diaplikasikan sehingga dapat meningkatkan pendapatannya.Serta berhasil pula membuat dan menampilkan web sistem informasi pemasaran sesuai dengan yang diharapkan. Diharapkan implementasi sistem Informasi pemasaran hasil produksi buah pala pada home industri ini mampu memudahkan masyarakat dalam belanja produk-produk yang berkualitas daerah khususnya Kabupaten Fakfak dan wilayah Indonesia pada umumnya serta memudahkan konsumen untuk belanja secara online.
\end{abstract}

Kata Kunci : sistem informasi, e-commerce, produk olahan pala 


\section{LATAR BELAKANG}

Perkembangan teknologi informasi dan komunikasi, dewasa ini, mengalami kemajuan yang sangat pesat, terlebih dengan semakin berkembangnya teknologi internet. Internet adalah jaringan global yang memanfaatkan salah satu media elektronik tercanggih (komputer) untuk memenuhi segala kebutuhan informasi dan komunikasi di segala bidang dengan akses yang sangat cepat ke seluruh dunia dan biaya yang relatif murah. Internet menyokong tumbuh kembang berbagai bidang yang berkaitan dengan kehidupan manusia, diantaranya pendidikan, kesehatan, serta perdagangan dan perindustrian.

Pertumbuhan ekonomi suatu daerah dapat diindikasikan oleh beberapa faktor, satu diantaranya adalah menggeliatnya sektor perindustrian yang dimiliki, baik industri skala besar, menengah, maupun skala rumah tangga. Perindustrian yang semakin bertumbuh dan berkembang ikut menopang kemajuan dan kesejahteraan suatu daerah, karena mampu memberikan kontribusi besar terhadap penciptaan kesempatan lapangan kerja dan sumber pendapatan dengan mengembangkan industri dapat menciptakan masyarakat yang mandiri dan maju.

Industri di wilayah kabupaten Fakfak pun mengalami kemajuan pesat dalam beberapa tahun terakhir, khususnya pada sektor industri rumah tangga (home industry). Namun usahausaha skala kecil yang dikelola oleh masyarakat setempat ini masih menggunakan teknologi yang relatif sangat sederhana atau tradisional, manajemen yang sangat sederhana, modal yang sangat kecil, serta pemasaran yang belum meluas dan terorganisir secara baik. Kebanyakan usaha kecil hingga saat ini masih dihadapkan pada permasalahan yang kompleks di bidang manajemen, diantaranya pengelolaan keuangan, pengendalian mutu produk dan pemasaran, bidang permodalan, bidang teknik produksi serta masalah-masalah lain yang menjadi penghambat bagi perkembangannya.

Pemasaran merupakan hal yang sangat krusial bagi sebuah usaha. Produk yang berkualitas didukung teknik produksi yang canggih, skill pekerja yang mumpuni, ataupun modal yang mencukupi tidak akan berarti banyak bagi sebuah bidang usaha tanpa didukung kemampuan memasarkan produk yang memadai. Berdasarkan hal tersebut, peneliti berinisiatif untuk memberikan kontribusi dalam pemasaran hasil produksi buah pala dan olahannya pada usaha kecil (home industry) pada kelompok usaha Vista di kampung Sekban kabupaten Fakfak. Pemasaran yang selama ini dilakukan kelompok Vista masih sangat sederhana dengan metode promosi dari mulut ke mulut sehingga dibutuhkan sebuah metode pemasaran modern yang dapat membantu kelompok tersebut dalam memasarkan hasil produksi buah pala dan hasil olahannya, agar mampu bersaing dengan produk-produk lainnya di pasaran. 


\section{IDENTIFIKASI MASALAH}

1. Pemasaran buah pala dan hasil olahannya pada home industry di Fakfak, khususnya home industry Vista masih berjalan secara tradisional dan sangat terbatas ruang lingkupnya.

2. Para pelaku home industry di Fakfak belum familiar dengan konsep electronic commerce (e-commerce) atau electronic marketing yang telah diakrabi pelaku home industry di daerah lain.

\section{BATASAN MASALAH}

1. Sistem ini dirancang atau didesain khusus sebagai sarana pemasaran hasil produksi buah pala dan olahannya pada kelompok usaha Vista di kampung Sekban kabupaten Fakfak.

2. Sistem dirancang dalam bentuk website dengan menampilkan produk yang dijual dan sekaligus dapat melakukan transaksi pemesanan produk.

\section{TUJUAN PENELITIAN}

1. Mengenalkan konsep pemasaran global dengan ruang lingkup yang lebih luas yang dapat diterapkan Home Industry Vista untuk meningkatkan pendapatannya dengan konsep ECommerce.

2. Membuat atau merancang sebuah website sebagai sistem informasi pemasaran produksi buah Pala dan hasil olahannya pada usaha kecil Vista di kampung Sekban kabupaten Fakfak.

\section{LANDASAN TEORI}

\section{Pemasaran}

Menurut William J. Stanton dan Charles Futrell (1987) dalam Sunyoto (2013:11): "Pemasaran adalah sistem keseluruhan dari kegiatan usaha yang ditujukan untuk merencanakan, menentukan harga, mempromosikan dan mendistribusikan barang, jasa, ide kepada pasar sasaran agar dapat mencapai tujuan organisasi”.

Definisi pemasaran menurut American Marketing Association (AMA: 2004) dalam Subroto (2011 : 1) adalah: "Marketing is an organizational function and a set of a processes for creating, communicating and delivering value to customers and for managing customer relationship, in ways that benefit the organization and stakeholders."

Dengan kata lain, pemasaran adalah proses penciptaan, pengkomunikasian, dan penyampaian nilai kepada pelanggan dan untuk mengelola hubungan baik dengan pelanggan, dengan cara yang menguntungkan baik bagi perusahaan maupun bagi pelanggan. Untuk 
manajemen pemasaran, menurut Kotler dan Keller (2009) dalam Sunyoto (2013 : 12), adalah sebagai seni dan ilmu memilih pasar sasaran meraih, mempertahankan serta menumbuhkan pelanggan dengan menciptakan, menghantarkan, dan mengkomunikasikan pelanggan yang unggul.

Pemasaran mempunyai peranan yang sangat menentukan karena pemasaran mempunyai kedudukan sebagai perantara antara produsen dengan konsumen. Pemasaran merupakan suatu urutan-urutan kegiatan yang saling berkaitan erat dan bertujuan untuk memuaskan kebutuhan dan keinginan manusia melalui proses pertukaran. Dengan demikian, dalam menjalankan usahanya, perusahaan perlu memperhatikan dan mengembangkan sistem pemasarannya.Masalah pemasaran merupakan salah satu aspek yang sangat penting bagi perusahaan untuk menjalankan roda perusahaannya karena tidak jarang perusahaan gagal mencapai tujuannya disebabkan sistem pemasaran yang kurang tepat.

Menurut Ratnasari dan Mastuti (2011:37) Bauran Pemasaran (Marketing Mix) merupakan tools bagi marketer yang berupa program pemasaran yang mempertajam segmentasi, targeting, dan positioning agar sukses. Marketing Mix Produk barang mencakup 4P; Product, Price, Place, and Promotion.

\section{a. Product (Produk)}

Product merupakan keseluruhan konsep objek atau proses yang memberikan sejumlah nilai manfaat bagi pelanggan. Yang perlu diperhatikan dalam product adalah pelanggan tidak hanya membeli fisik dari product itu saja, tetapi membeli benefit dan value dari product itu yang disebut "The Offer".

b. Price (Harga)

Price adalah sejumlah kompensasi (uang maupun barang) yang dibutuhkan untuk mendapatkan kombinasi barang atau jasa.Dalam hal ini, harga yang ditetapkan oleh perusahaan, harus dapat menutup semua biaya yang telah dikeluarkan untuk produksi ditambah besarnya persentase laba yang diinginkan.

c. $\quad$ Place (Tempat)

Place adalah gabungan antara lokasi dan keputusan atas saluran distribusi (berhubungan dimana lokasi yang strategis dan bagaimana cara penyampaian produk pada pelanggan). Saluran Distribusi (Place) merupakan saluran yang digunakan oleh produsen untuk menyalurkan produk maupun jasa kepada konsumen atau berbagai aktivitas perusahaan yang mengupayakan agar produk sampai ke tangan konsumen. 


\section{d. Promotion (Promosi)}

Promotion adalah kegiatan-kegiatan yang secara aktif dilakukan perusahaan untuk mendorong konsumen membeli produk yang ditawarkan. Yang perlu diperhatikan dalam promosi adalah bauran promosi (promotion mix) yang terdiri atas: (1) advertising, (2) personal selling, (3) sales promotion, (4) public relation, (5) word of mouth, dan (6) direct mail marketer.

\section{E-Commerce}

Menurut Ahmadi dan Hermawan, (2013:7) E-Commerce adalah penjualan atau pembelian barang dan jasa, antar pergusahaan, rumah tangga, individu, pemerintah, dan masyarakat atau organisasi swasta lainnya, yang dilakukan melalui computer pada media jaringan.

E-Commerce merupakan bagian dari E-Business, tetapi E-Business tidak terbatas pada pengadaan dan kegiatan penjualan.Berbeda dengan E-Business, E-Commerce berkaitan dengan transaksi dimana pemesanan dilakukan secara elektronik, pembayaran dan pengiriman dapat dilakukan offline maupun online.

Istilah "perdagangan elektronik" telah berubah sejalan dengan waktu.Awalnya perdangan elektronik berarti pemanfaatan transaksi komersial, seperti penggunaan EDI untuk mengirim dokumen komersil seperti pesanan pembelian atau invoice secara elektronik.Kemudian berkembang menjadi suatu aktivitas yang mempunyai istilah yang lebih tepat; "perdagangan web" - pembelian barang dan jasa melalui World Wide Web melalui server aman (HTTPS), protocol server khusus yang menggunakan enkripsi untuk merahasiakan data pelanggan.

Dengan munculnya E-Commerce, organisasi tersebut sekarang memiliki kesempatan untuk melewati distributor dan perdagangan secara langsung dengan pelanggan melalui situs web. E-Commerce merujuk pada semua bentuk transaksi komersial yang menyangkut organisasi dan individu yang didasarkan pada pemrosesan dan transmisi data yang 
didigitalisasikan, termasuk teks, suara, dan gambar.Perdangan dilakukan melalui jaringan elektronik dengan penggunaan komputer untuk memudahkan semua operasi perusahaan.

Model bisnis E-Commerce merupakan metode melakukan usaha yang dapat menghasilkan pendapatan bagi perusahaan untuk menjamin kelangsungan hidupnya.

\section{a. Brokerage}

1. Membawa pembeli dan penjual pada satu tempat yang sama dan menjadi fasilitator transaksi.

2. Model penghasilannya terutama dari biaya persen per transaksi yang terjadi.

b. Advertising

1. Merupakan pengembangan dari model broadcasting (penyiaran) tradisional.

2. Dalam hal ini yang menjadi broadcaster (penyiar) adalah situs web yang menyediakan content (isi) dan services (layanan) dikombinasikan dengan advertising message (iklan) yang terletak di banner.

3. Model penghasilannya terutama dari biaya pemasangan banner.

4. Model ini hanya bisa berjalan apabila traffic dari situs web broadcaster (penyiar) cukup besar/sering dikunjungi.

c. Infomediary

1. Data mengenai pembeli dan kebiasaan membeli mereka sangat penting. Data tersebut kemudian digunakan sebagai bahan analisis.

2. Hasil analisis tersebut dijual ke pihak ketiga yang memerlukan.

\section{d. Merchant}

1. Model bisnis ini merupakan bentuk elektronik dari penjualan barang secara grosir maupun eceran (retail).

2. Penjualan bisa melalui harga yang ada maupun melalui lelang. 


\section{e. Manufaktur}

1. Kata manufaktur berasal dari bahasa Latin, manus factus yang berarti dibuat dengan tangan. Manufaktur, dalam arti yang paling luas, adalah proses mengubah bahan baku menjadi produk. Manufaktur adalah suatu cabang industry yang mengaplikasikan mesin, peralatan, tenaga kerja, dan suatu medium proses untuk mengubah bahan mentah menjadi barang jadi untuk dijual.

2. Perusahaan brick and mortar, yang sudah mempunyai basis industri sendiri, membuat web untuk beberapa tujuan:

a) Memperpendek rantai distribusi produk dengan akses langsung ke pemakai.

b) Meningkatkan pelayanan dan mengetahui kebutuhan pelanggan secara langsung.

\section{f. Afiliasi}

1. Afiliasi merupakan cara menghasilkan uang dengan menjual produk dari perusahaan atau lembaga pemilik produk (affiliate merchant) dengan bergabung menjadi pemasar produk (affiliate marketers) dan hanya dibayar setelah produk terjual

2. Model bisnis yang memungkin afiliasi antarsitus web E-Commerce untuk melakukan promosi/penjualan di internet.

\section{g. Komunitas}

Berbasiskan pada kepuasan pengunjung situs, pada beberapa kasus, pengunjung merupakan penyumbang isi dan pendapatan dari situs web tersebut.

\section{h. Subscription}

1. Pengunjung membayarkan sejumlah uang pada saat akan mengakses situs tersebut. Isi situs tersebut merupakan informasi yang bernilai tinggi.

2. Pengunjung dikenakan biaya berdasrkan banyaknya fasilitas yang diakses pada situs web tersebut. Umumnya, situs web untuk payment gateway kartu kredit. 


\section{PEMBAHASAN DAN HASIL}

Kelompok Usaha (Home Industry) Vista adalah salah satu kelompok usaha masyarakat yang berada di kabupaten Fakfak. Kelompok usaha ini menlaukukan usaha perdagangan buah pala dan hasil olahannya.

Selama menjalankan usaha selama beberapa tahun belakangan ini, Kelompo Usaha Vista melakukan pemasaran dengan cara tradisional, dimana produk dijual dengan memajang di depan rumah salah satu anggota kelompok usaha serta melakukan promosi dari mulut ke mulut.

Hasil yang diperoleh dari pemasaran tradisional yang dilakukan selama ini tentu masih dangat jauh dari yang diharapkan. Oleh karena itu dengan merancang dan mengaplikasikan sistem informasi pemasaran yang berbasis web ini diharapkan akan semakin meningkatkan jumlah transaksi jual beli produk kelompok usaha Vista yang pada akhirnya akan mampu menigkatkan taraf hidup anggotanya

\section{Perancangan Basis Data}

Proses perancangan basis data merupakan tahap penting agar sistem yang digunakan lebih efisien dalam penyimpanan data. Adapun rancangan database terdiri dari 5 (lima) tabel antara lain:

\section{a. Tabel Login}

Tabel ini digunakan untuk akses login admin

\begin{tabular}{|l|l|l|l|c|}
\hline No & Nama & Tipe Data & Range Data & Keterangan \\
\hline 1 & Id & Int & 11 & Primary \\
\hline 2 & Username & Varchar & 20 & - \\
\hline 3 & Password & Varchar & 20 & - \\
\hline
\end{tabular}

b. Tabel Barang

Tabel ini digunakan untuk akses input barang:

\begin{tabular}{|l|l|l|l|c|}
\hline No & Nama & Tipe Data & Range Data & Keterangan \\
\hline 1 & kode_barang & Int & 11 & Primary \\
\hline 2 & nama_barang & Varchar & 50 & - \\
\hline 3 & warna_barang & Varchar & 20 & - \\
\hline
\end{tabular}




\begin{tabular}{|l|l|l|l|c|}
\hline 4 & harga_barang & Varchar & 25 & - \\
\hline 5 & stok_barang & Int & 5 & - \\
\hline 6 & Gambar & Varchar & 45 & - \\
\hline
\end{tabular}

c. Tabel Pembelian

Tabel ini digunakan untuk akses input pembelian barang:

\begin{tabular}{|l|l|l|l|c|}
\hline No & Nama & Tipe Data & Range Data & Keterangan \\
\hline 1 & id_supplier & Int & 11 & Primary \\
\hline 2 & nama_supplier & Varchar & 50 & - \\
\hline 3 & nama_barang & Varchar & 45 & - \\
\hline 4 & harga_beli & Varchar & 20 & - \\
\hline 5 & jumlah_barang & Int & 5 & - \\
\hline 6 & total_beli & Varchar & 20 & - \\
\hline
\end{tabular}

d. Tabel penjualan

Tabel ini digunakan untuk akses input penjualan barang:

\begin{tabular}{|l|l|l|l|c|}
\hline No & Nama & Tipe Data & Range Data & Keterangan \\
\hline 1 & id_penjualan & Int & 11 & Primary \\
\hline 2 & kode_barang & Int & 11 & - \\
\hline 3 & nama_barang & Varchar & 50 & - \\
\hline 4 & nama_pemesan & Varchar & 45 & - \\
\hline 5 & Email & Varchar & 35 & - \\
\hline 6 & jumlah_pesanan & Int & 4 & - \\
\hline 7 & Alamat & Varchar & 50 & - \\
\hline 8 & Telepon & Varchar & 15 & \\
\hline
\end{tabular}

e. Tabel komentar

Tabel ini digunakan untuk akses input komentar: 


\begin{tabular}{|l|l|l|l|c|}
\hline No & Nama & Tipe Data & Range Data & Keterangan \\
\hline 1 & Nama & Varchar & 50 & - \\
\hline 2 & Email & Varchar & 45 & - \\
\hline 3 & Komentar & Varchar & 150 & - \\
\hline
\end{tabular}

\section{Tampilan Web User}

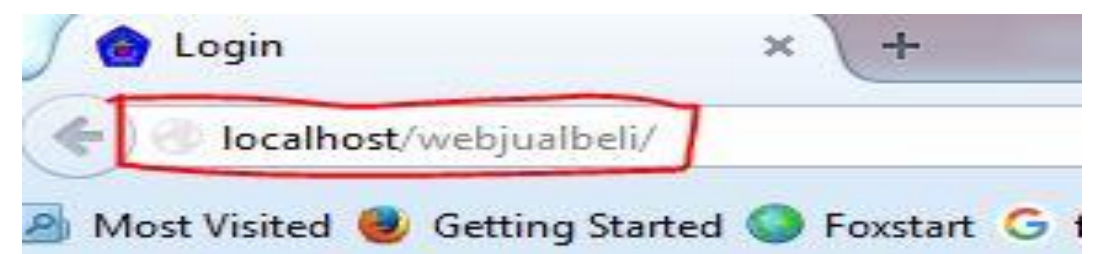

Gambar 1. Tampilan Halaman Link untuk user

Gambar 1 menampilkan link untuk membuka web browser. Ketik localhost/webjualbeli untuk masuk pada tampilan awal website.

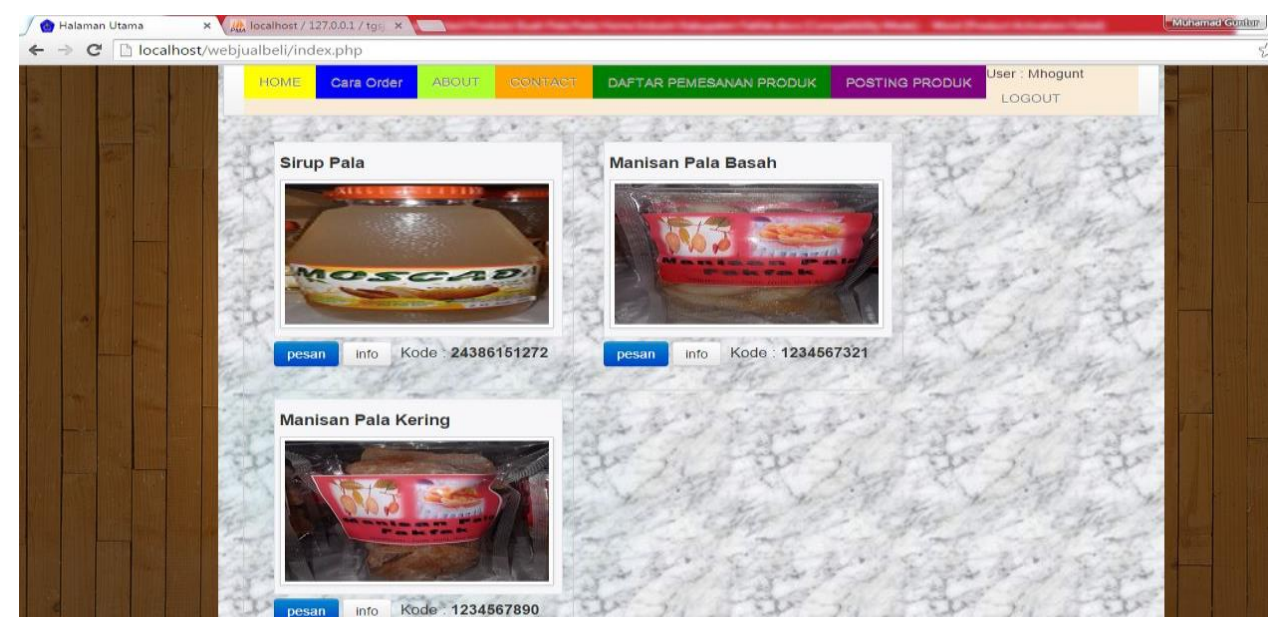

Gambar 2 Tampilan Halaman Utama

Gambar 2 adalah tampilan halaman utama website, bila telah berada di halamn ini berarti user telah berhasil masuk ke website. 
Gambar 3 Tampilan Halaman Informasi.

Gambar 3 merupakan tampilan halaman website yang memberikan informasi kepada user tentang harga produk yang dijual.

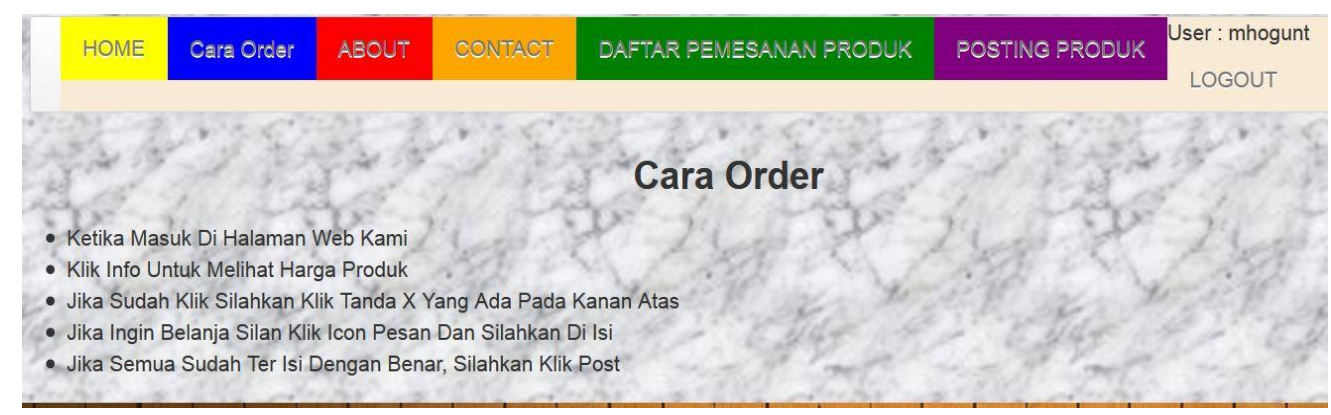

Gambar 4 Cara Order Barang

Gambar 4 adalah tampilan halaman penjelasan kepada user tentang langkah-langkah untuk membeli produk pada website home industry Vista.

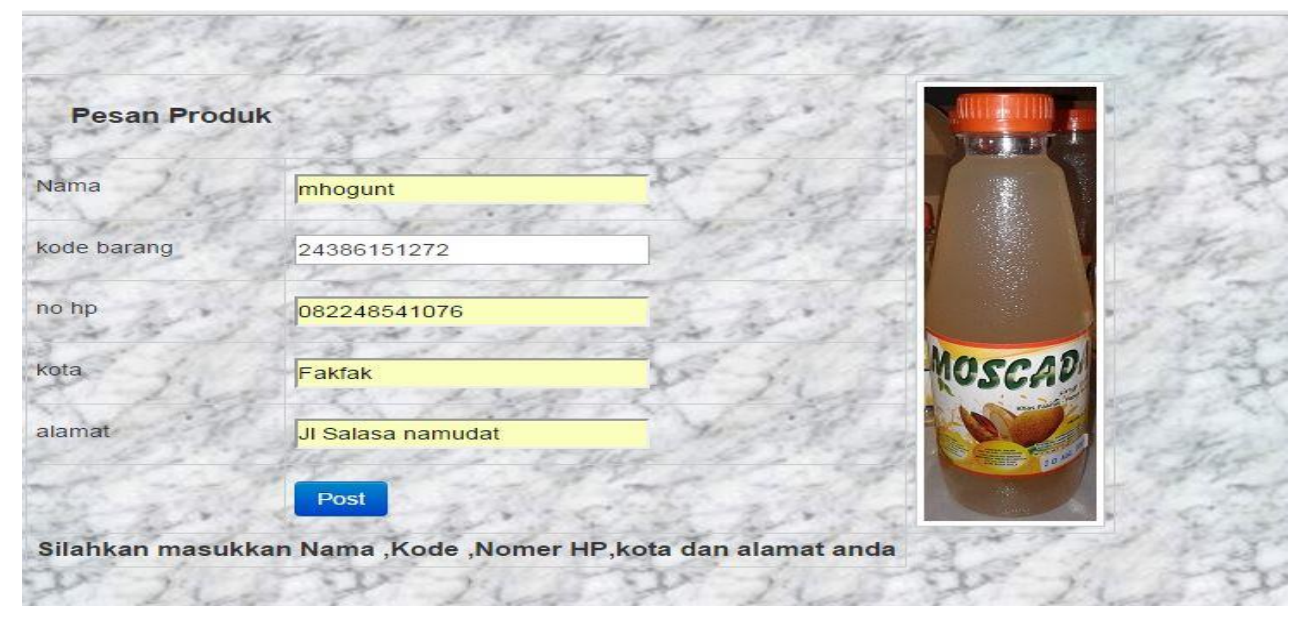

Gambar 5 Tampilan halaman Pemesanan Produk 
Gambar 5 merupakan tampilan halaman pemesanan produk yang akan dipesan oleh user dan user harus mengisi kolom tersebut agar dengan mudah dapat dihubungi oleh pihak Vista. Jika sudah klik icon post.

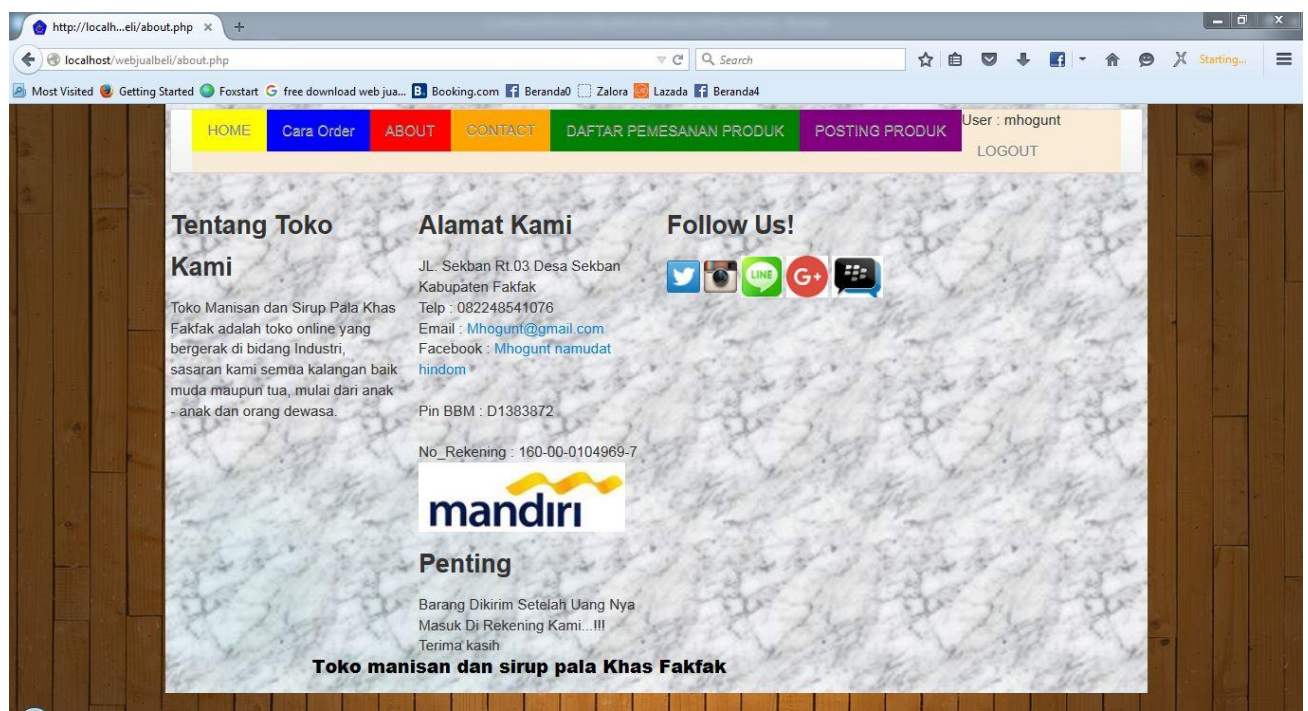

Gambar 6 Tampilan mengenai Toko

Gambar 6 di atas menjelaskan tentang alamat yang user harus hubungi, agar barang dapat di antar kepada user.

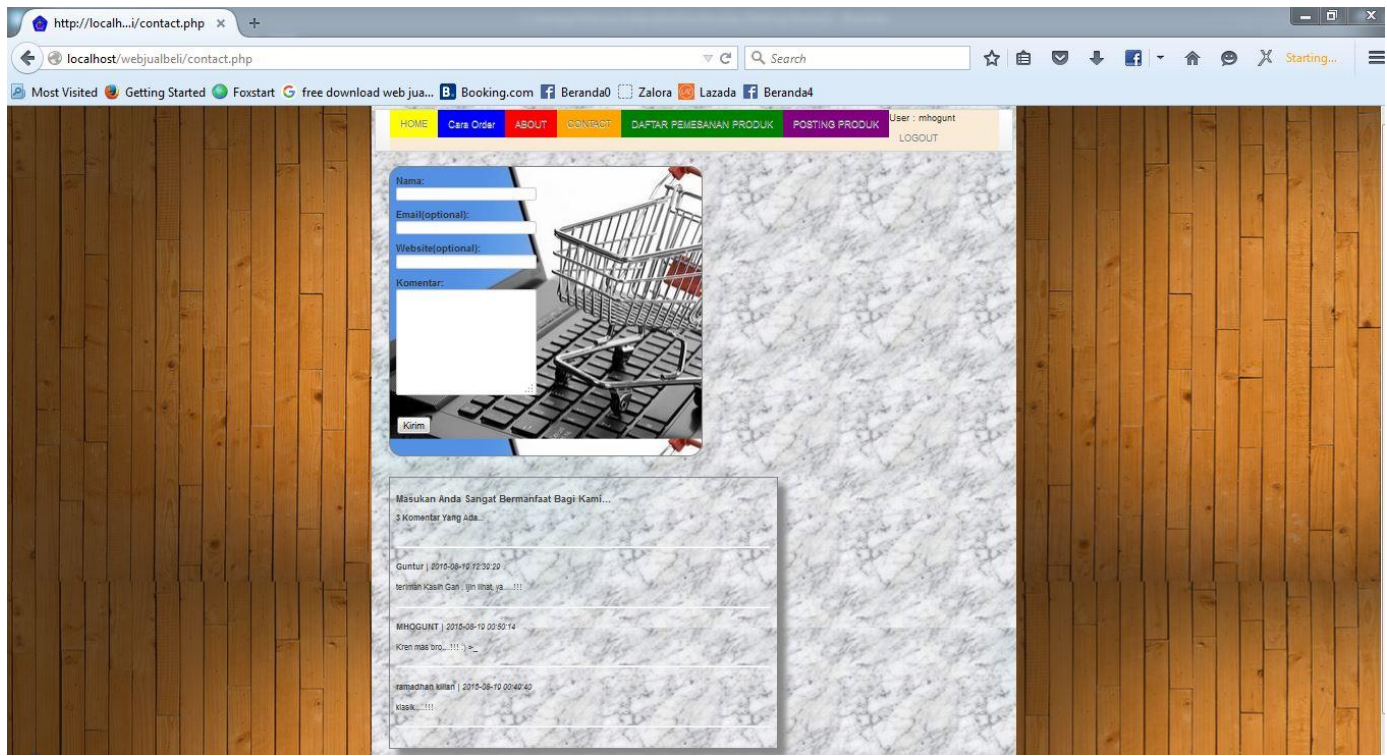

Gambar 7 Tampilan Halaman Masukan untuk Admin 
Gambar 7 di atas menjelaskan bagaimana user dapat memberikan komentar atau masukan kepada admin dalam rangka pengembangan web.

\section{Tampilan Web Admin}

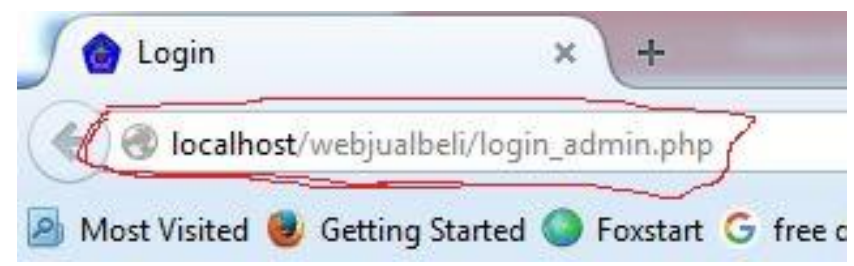

Gambar 8 Tampilan halaman Link untuk akses ke halaman admin

Gambar 8 menjelaskan tentang admin harus mengetik localhost/webjualbeli/login_admin.php agar dapat masuk pada tampilan form login admin.

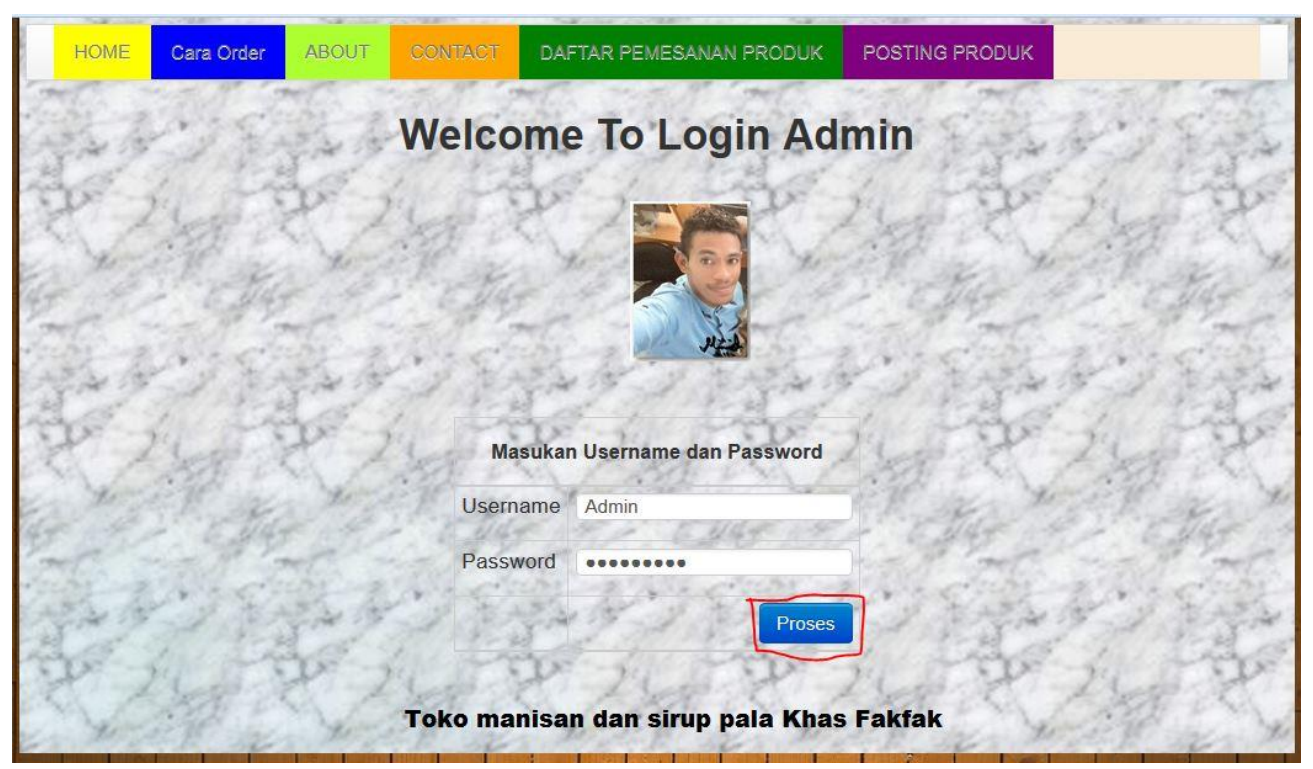

Gambar 9 Tampilan Halaman Admin.

Gambar 9 merupakan tampilan halaman login admin jika username dan password telah diisi kemudian klik proses untuk masuk pada halaman admin. 


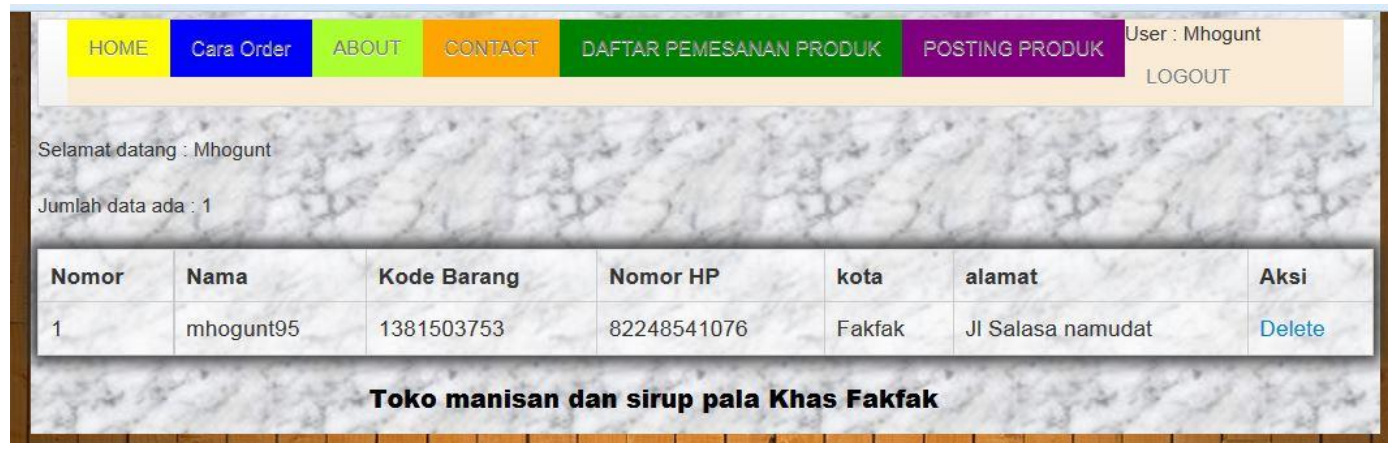

Gambar 10 Tampilan Halaman Daftar Pemesan

Gambar 10 adalah tampilan halaman user yang telah memesan produk.

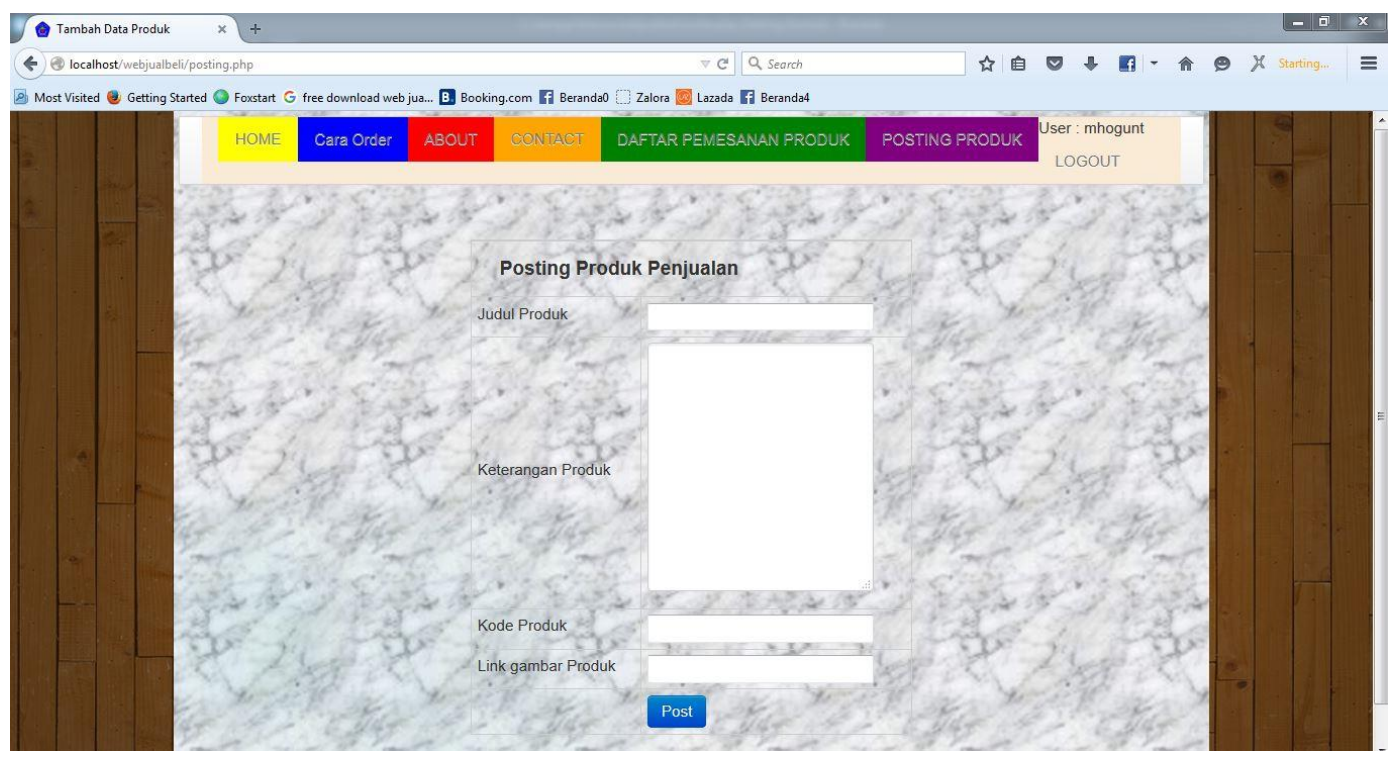

Gambar 11 Tampilan Halaman Postingan Produk.

Gambar 11 merupakan tampilan halaman postingan produk yang akan ditampilkan pada halaman home.

\section{KESIMPULAN DAN SARAN}

Berdasarkan hasil penelitian dan pengamatan yang telah dilakukan, dapat disimpulkan bahwa:

1. Konsep pemasaran dengan berbasis aplikasi (e-commerce) telah berhasil dikenalkan kepada home industry Vista dan dapat diaplikasikan sehingga dapat meningkatkan jumlah penjualan produk olahan Pala.

2. Web ini telah berhasil dibuat dan dapat ditampilkan sesuai dengan yang diharapkan. Diharapkan implementasi sistem Informasi pemasaran hasil produksi buah pala pada home industry ini mampu 
memudahkan masyarakat dalam belanja produk-produk yang berkualitas khususnya di Kabupaten Fakfak dan wilayah Indonesia pada umumnya serta memudahkan konsumen untuk berbelanja online.

Saran yang dapat diberikan berdasarkan penelitian ini adalah:

1. Ke depan diharapkan sistem informasi pemasaran hasil produksi buah pala ini dapat dioperasikan lebih luas lagi dengan ruang lingkup global dan diterapkan juga atas hasil produksi unggulan lainnya sehingga dapat mendatangkan keuntungan bagi industriindustri kecil yang ada di kabupaten Fakfak.

2. Perlu adanya perhatian khusus dari Pemerintah Daerah terkaitkan dengan pelatihanpelatihan secara rutin tentang cara pembuatan berbagai jenis produk dari buah pala agar kualitasnya dapat dipertahankan.

\section{REFERENSI}

Anamisa, D. R., \& Kustiyahningsih, Y. (2010). Pemrograman Basis Data Berbasis Web Menggunakan PHP dan MySQL. Jakarta: Graha Ilmu.

Baihaqi, A. P. (2013). Membuat Aplikasi Rental Movie dengan Visual Basic 6.0. Elex Media Komputindo.

Brady, M., \& Loonam, J. (2010). Exploring the use of entity-relationship diagramming as a technique to support grounded theory inquiry. Qualitative Research in Organizations and Management: An International Journal, 5(3), 224-237.

Davis, G. B., \& Olson, M. H. (1984). Management information systems: conceptual foundations, structure, and development. McGraw-Hill, Inc.

Jogiyanto, H. M. (2017). Analisis dan Desain (Sistem Informasi Pendekatan Terstruktur Teori dan Praktek Aplikasi Bisnis). Penerbit Andi.

Ladjamudin, A. B. B. (2005). Analisis dan desain sistem informasi. Yogyakarta: Graha Ilmu.

Li, E. Y., Mcleod Jr, R., \& Rogers, J. C. (2001). Marketing information systems in Fortune 500 companies: a longitudinal analysis of 1980, 1990, and 2000. Information \& Management, 38(5), 307-322.

Mulyanto, A. (2009). Sistem Informasi konsep dan aplikasi. Yogyakarta: Pustaka Pelajar.

Nugroho, B. (2008). Panduan Lengkap Menguasai Perintah SQL. MediaKita.

Sadeli, M. (2009). Aplikasi Mini Market dengan Visual Basic 6.0. Palembang: Maxicom.

Sulhan, M. (2007). Pengembangan Aplikasi Berbasis Web dengan PHP dan ASP. Penerbit Gava Media, Yogyakarta. 